\title{
THE LIFE OF A STATE IN THE HUMAN DIMENSION
}

The human dimension of state transformations is a delicate and controversial matter. Unrestrained human desires and the emotionality of human relationships have contributed equally to the historical background of events, while the unpredictability of human destiny has animated and painted historical patterns in vivid colors, thus causing ambiguity and nonlinearity in social movements. Such nonlinearity attracts the attention of modern scholars reassessing events during the reign of Peter the Great and the participation of domestic and foreign experts in nation-building. The notion of public good was a precondition for preserving information about the individual fates of people, something that is reflected in collections of documents.

In the Problema voluminis section, Quaestio Rossica follows up the theme raised at a conference in Paris in 2017: the process of familiarizing Russia with European culture as a public act, the results and implementation of which can be seen in the lives of different social classes. Peter the Great's second voyage to Europe (1716-1717) caused a wave of events that influenced the careers of Peter's statesmen, the promotion of reforms and the emergence of new artefacts. The articles that focus on this important journey were presented as papers at the aforementioned Paris conference; the selection offered here is discussed in detail in the editorial by Professor Francine-Dominique Liechtenhan (Université Paris-Sorbonne (Paris IV), the journal's editor-in-chief.

The second part of this section features original materials on cultural diplomacy, thus discussing the notion of 'soft power' that has gained new significance today. The ability to use art in diplomacy was typical in imperial history, as is shown in the study by Ludmila Budrina (Ekaterinburg Museum of Fine Arts). Budrina demonstrates how the unique works of stone-carving masters from the Urals - giant luxurious vases carved from precious malachite - served as investment projects and the expressions of imperial gratitude. The article by Evgeniya Konysheva (South Ural State University, Chelyabinsk) about the USSR Pavilion at the 1937 World Fair in Paris investigates the way in which Stalin's cultural diplomacy combined grandiosity and the audacity of modern forms and materials in order to establish a personality cult of the leaders of the Revolution. The tragic fates of the creators of the 'Soviet miracle' pavilion were apparently a repayment for the paradoxical combination of genius and mendacity embodied in the Parisian exhibition.

Quaestio Rossica is pleased to introduce a new section, Conceptus et conceptio, and invites scholars to present new theories and controversial concepts in it. The section opens with an article by Andrey Epimakhov (Institute of History and Archaeology of the Urals Branch of RAS, Ekaterinburg) on frontier theory and the archaeology of the Bronze Age in the Urals. The 
value of this interesting theoretical article is certainly increased by the default 'resistance' of the concepts and materials that qualify archaeology as a science. Alexander Kamensky (Higher School of Economics, Moscow) has devoted his piece to the popular myth of 'centennial Russian backwardness'. The author deconstructs the constituents of this concept and considers the limits of this stereotypical understanding of Russian history, inviting the reader to rethink convenient trivialities. An ad hoc dialogue between Russian historians and scholars at the University of Michigan on processes of migration throughout Russian history is offered by the article of Oleg Gorbachev (Ural Federal University, Ekaterinburg): this elegantly mirrors the work co-authored by Lewis H. Siegelbaum and Leslie Page Moch.

The Disputation section of Quaestio Rossica hosts an article on NGOs in the post-Soviet space by the historians Valery Yungblud and Artyom Zboev (Vyatka State University, Kirov). A hot theme with the Russian authorities and society alike, it presents an impartial and objective analysis based on the reports submitted by the NGOs themselves.

In the Scientia et vitae section, Dr Reinhard Nachtigal (University of Freiburg) pays tribute to the German historian and philologist Gottfried Schramm (1929-2017), presenting his academic biography to readers of the journal with great affection. Schramm's research was distinguished by a particular understanding of scientific integrity and the ability to confront common beliefs. His competence in defending argumentative statements demanded not just audacity, but also true courage in a very direct sense of the word. His research was focused on understanding language as a key to world culture, including the Slavic part of it.

The Controversiae et recensiones section features an expertly composed analytical review by Olga Kosheleva (Institute of World History, RAN, Moscow) concerning the controversial characteristics of the pre-Petrine era. The findings of the article most certainly deserve the closest attention of the reader, both in terms of the coverage of important research and the conceptual interpretation of the material. Yulia Matveeva (Ural Federal University, Ekaterinburg) reviews an exceptionally informative and valuable study of the aliases of the Russian literary diaspora, edited by M. Shruba and O. Korosteleva. The study is an indispensable aid for scholars studying Russian overseas literature. The work accomplished by the authors demonstrates a meticulous approach to, and truly comprehensive coverage of, the material, making the article an absolute must for studying Russian literature in the diaspora. Yulia Podlubnova (Institute of History and Archaeology of the Urals Branch of RAS, Ekaterinburg), reviewing the book of A. Bruno about the exploration of the Arctic during Soviet times, correctly notes the work's relationship with modern environmental theories, an interesting twist that turns it into a study of the Soviet environmental experience in global context.

Larisa Soboleva

(Ural Federal University) 
Человеческое измерение государственных преобразований тонкий и противоречивый инструмент. Необузданность желаний и эмоциональная составляющая людских взаимоотношений также формировали событийный исторический фон, а непредсказуемость человеческих судеб оживляла и раскрашивала разными красками исторические закономерности, заставляя сомневаться в однозначности и прямолинейности векторов социального движения. Эти сложности привлекают внимание современной гуманитарной науки в связи с осмыслением событий Петровской эпохи, участия отечественных и иностранных специалистов в государственном строительстве. Государственные интересы были условием хранения информации о судьбах людей, отражаясь в комплексе документов.

В рубрике Problema voluminis продолжается тема, поднятая на конференции в Париже в 2017 г. ${ }^{1}$, - процесс приобщения России к европейской культуре как государственное деяние, результаты и выражение которого претворяются в судьбах разных сословий. Второе путешествие Петра Первого в Европу вызвало волну событий, повлияло на карьеры сподвижников государя, привело к продвижению реформаторских идей и появлению новых артефактов, что демонстрируют посвященные ему исследования. Статьи, представленные в данной части рубрики, звучали как доклады на парижской конференции и освещаются в размышлениях главного редактора журнала профессора Ф.-Д. Лиштенан, которыми мы открыли первый выпуск шестого тома Quaestio Rossica.

Во второй части рубрики приведены оригинальные материалы о культурной дипломатии - той «мягкой силе», которая обретает сегодня новые достоинства.

Умение использовать в дипломатии предметы искусства было свойственно имперской истории, как показывает исследование Людмиль Будриной (Екатеринбургский музей изобразительных искусств). Уникальные произведения камнерезных мастеров Урала - малахитовые вазы - становятся факторами инвестиционных проектов и выражением имперской благодарности. Сталинская культурная дипломатия, сочетающая грандиозность замысла, смелость и даже дерзость использования современных форм и материалов для утверждения культа личности вождей революции, описана в статье Евгении Конышевой (Южно-Уральский университет, Челябинск) о павильоне СССР на Всемирной выставке 1937 г. в Париже. Трагические судьбы творцов советского чуда явились платой за парадоксальное сочетание гениальности и фальши, свойственное парижскому феномену.

С этого номера журнал вводит рубрику Conceptus et conceptio, приглашая ученых к изложению новых теорий и спорных концепций. Открывает ее статья Андрея Епимахова (Институт археологии и истории УрО РАН) о теории фронтира и археологии бронзового века на уральском материале. Ценность статьи возрастет, если учесть сопротивление

\footnotetext{
${ }^{1}$ Публикацию результатов конференции см.: Quaestio Rossica. 2017. T. 5. № 3.
} 
концепции и материала, присущее археологии как науке с преимущественным вниманием к «вещественности» культуры. Распространенному мифу о «вековой русской отсталости» посвящена статья Александра Каменского (Высшая школа экономики, Москва). Автор рассматривает грани данного концепта и ограниченность стереотипного понимания российского исторического пути, приглашая к переосмыслению прежних тривиальных истин. Своеобразный диалог российской научной школы и ученых Мичиганского университета относительно процесса миграции в российской истории представлен статьей Олега Горбачева (УрФУ), ставшей репликой к совместной статье Льюиса Сигельбаума и Лесли Мох (Университет Мичигана, США).

Волнующая в последнее время российскую власть и общество тема деятельности НПО на постсоветском пространстве раскрывается в объективном анализе, основанном на отчетах обществ, данном в статье историков Валерия Юнгблюда и Артема Збоева (Вятский университет) (рубрика Disputatio).

Трудный, требующий огромной эрудиции и аналитических навыков жанр обзора представлен в статье Ольги Кошелевой (Институт истории РАН, Москва). Он касается противоречивой характеристики предпетровского времени (рубрика Controversiae et recensiones). Выкладки ученого достойны самого пристального внимания русскоязычного читателя как в плане освещения важных исследований, так и в плане новых концептуальных трактовок материала. Рецензия на чрезвычайно информативную и полезную работу - исследование псевдонимов русского зарубежья под редакцией М.Шрубы и О. Коростелева, как показывает Ю. Матвеева (УрФУ), становится необходимой книгой для филологов, изучающих этот пласт литературы. Проделанная авторами работа отличается тщательностью и поистине всеобъемлющим охватом материала, что придает ей функцию необходимого справочника для исследователя зарубежной русской литературы. В рецензии Юлии Подлубновой (Институт истории и археологии УрО РАН) на книгу А. Бруно об освоении Арктики в советское время отмечается ее связь с современными теориями экологии земли, что превращает ее в исследование, касающееся осмысления советского опыта в мировом контексте.

Лариса Соболева (Уральский федеральньй университет) 